\title{
PROBLEMATIKA DAN DINAMIKA PERBANKAN SYARIAH DI ERA GLOBALISASI
}

\author{
Zulfadli Nugraha Triyan Putra ${ }^{1}$, \& Husni Thamrin \\ ${ }^{1 \& 2}$ Program Studi Ekonomi Syariah, Pasca Sarjana Universitas Islam Negeri SUSKA Riau \\ Email :fadhlee.jones@gmail.co.id,husni2017husni@gmail.com
}

\begin{abstract}
ABSTRAK
Penelitian ini bertujuan untuk menganalisa faktor eksternal dan internal yang mempengaruhi perkembangan perbankan syariah di Indonesia. Dalam membahas problematika dan dinamika perbankan syariah di era globalisasi ini penulis menggunakan jenis dan sumber data yang didapat dari riset perpustakaan (library research) dengan mengadopsi pemikiran dan pendapat para ahli yang memiliki keterkaitan secara langsung atau tidak langsung dengan topik yang sedang dibahas. Perbankan syariah lahir untuk menjadi alternatif bagi masyarakat yang menginginkan bertransaksi dengan sistem syariah, ada beberapa faktor yang menjadi keunggulan bank syariah jika dibandingkan dengan bank konvensional yakni : menyertakan nilai-nilai ketuhanan dalam setiap transaksi, adanya keterikatan emosional secara religi antara bank dan nasabah, adanya keadilan dalam bagi hasil simpanan dan pembiayaan. Akan tetapi disisi lain mereka dihadapkan pada problematika yang membuat mereka sulit untuk berkembang. Faktor keterbatasan kemampuan SDM, minimnya sosialisasi dan edukasi kepada masyarakat, kurangnya pemahaman dan animo umat serta keterbatasan layanan terhadap pelanggan menjadi penghambat bagi bank syariah. Agar tetap eksis dan berkembang, bank syariah harus mampu menerobos dominasi bank konvensional dengan kekuatan korelasi antara pemerintah, institusi pendidikan serta inovasi dari pihak bank syariah itu sendiri. Bank syariah juga dituntut untuk lebih adaptif dan inovatif terhadap kebutuhan pangsa pasar.
\end{abstract}

Kata Kunci : Problematika, Globalisasi, Perbankan Syariah.

\begin{abstract}
This study aims to analyze the external and internal factors that influence the development of syariah banking in Indonesia. In analyzing the Problems and Dynamics of Islamic Banking system in the Era of Globalization, the author uses the types and sources of data obtained from library research by adopting the thoughts and opinions of experts who have direct or indirect relevance to the topic being discussed. Islamic banking was born to be an alternative for people who want to transact with the sharia system, There are several factors that become the advantages of Islamic banks when compared to conventional banks, namely; include divine values in every transaction, there is a religious emotional attachment between the bank and the customer, there is fairness in the sharing of savings and financing. But, in the other side they are faced with problems that make it difficult for them to develop. The human resource capacity factor, the lack of socialization and education to the community, the lack of understanding and interest of the people and the limited service are obstacles for Islamic banking. In order to continue to exist and develop, Islamic banks must be able to break through the dominance of conventional banks with the strength of the correlation between the government, educational institutions and the innovation of Islamic bank itself. Islamic banking are also required to be more adaptive and innovative to the needs of market share.
\end{abstract}

Keywords: Problematic, Globalization, Sharia Banking System. 


\section{PENDAHULUAN}

Perbankan syariah merupakan sistem perbankan yang menjunjung tinggi dengan nilai-nilai ketuhanan dalam setiap transaksinya dan mengedepankan unsur maslahat. Keberadaan bank syariah dilegalisasi oleh Undang-undang Nomor 07 Tahun 1992 sebagai jenis bank yang boleh beroperasi di Indonesia, pemerintah kemudian menerbitkan Peraturan Pemerintah Nomor 72 Tahun 1992 sebagai petunjuk operasional atau menjelaskan prinsip bagi hasil yang ada dalam Undang-undang Nomor 07 Tahun 1992.

Legalisasi bank syariah juga didukung oleh lembaga Majelis Ulama Indonesia, Sjahdaini (2009) penelitiannya menyebutkan bahwa Fatwa MUI No. 27 tahun 1990 secara jelas menyatakan bahwa bunga bank adalah haram. Sebagai bank dengan prinsip syariah yang beroperasi dinegara yang mayoritas penduduknya adalah beragama Islam, bank syariah seharusnya bisa berkembang lebih pesat dan mendominasi pangsa pasar perbankan nasional.

Kuartal pertama tahun 2021 perbankan syariah hanya mampu meraup sekitar 9,96\% dari total keseluruhan nasabah perbankan nasional, selebihnya masih dikuasai oleh bank konvensional.

Faktor keterbatasan kemampuan SDM pengelola bank syariah, minimnya sosialisasi dan edukasi tentang visi dan praktek perbankan syariah kepada masyarakat umum yang menjadikan kurangnya pemahaman masyarakat tentang perbankan syariah dan rendahnya minat untuk melakukan transaksi melalui bank syariah, serta keterbatasan layanan terhadap nasabah oleh bank-bank syariah menjadi hambatan bagi bank syariah. Untuk itu diperlukan adanya terobosan-terobosan yang dapat menjadi solusi dan membantu perkembangan perbankan syariah di era globalisasi sekarang ini.

\section{TINJAUAN PUSTAKA}

Ekonomi secara sederhana dapat diartikan sebagai kegiatan atau tingkah laku untuk pemenuhan kebutuhan (rumah tangga), sedangkan syariah merupakan konsep yang merujuk pada ajaran agama tertentu yang dalam hal ini adalah agama Islam. Konsep syariah ini berlandaskan pada dua sumber hukum utama dalam ajaran agama Islam yakni Al Qur'an dan Hadits.

Jaharuddin dan Sutrisno (2019) mendefinisikan ekonomi syariah sebagai penerapan konsep-konsep Al Qur'an dan Hadits, baik secara langsung ataupun tidak langsung dalam kegiatan perekonomian. Dalam konsep sistem ekonomi syariah kegiatan ekonomi tidak hanya sekadar memandang kepada unsur untung atau rugi dalam suatu transaksi, akan tetapi lebih melihat pada keabsahan atau kesesuaian transaksi tersebut dalam ajaran agama Islam.

$$
\text { Menurut Prasetyo }
$$

penelitiannya menyebutkan ada beberapa karakteristik ekonomi syariah:

\section{a. Ekonomi Ketuhanan}

Ekonomi syariah berasal dari wahyu Allah SWT dalam bentuk syariat Islam, ekonomi syariah ini adalah bagian dari pengamalan ajaran agama Islam.

b. Ekonomi Pertengahan

Ekonomi syariah ini mempunyai keseimbangan antara berbagai aspek sehingga sering di istilahkan dengan ekonomi pertengahan. Ekonomi pertengahan ini memandang keseimbangan antara hak invidu dan masyarakat, keseimbangan antara jiwa dan raga serta keseimbangan antara dunia dan akhirat.

\section{c. Ekonomi berkeadilan}

Ekonomi syariah sangat memperhatikan aspek keadilan bagi semua pihak yang terkait dalam praktek ekonomi syariah. Hal ini turunan dari karakteristik ekonomi syariah pada poin pertama yakni ekonomi ketuhanan.

Lembaga Perbankan merupakan inti dari sistem keuangan dari setiap negara. dimana bank berfungsi sebagai lembaga keuangan yang menjadi tempat bagi perorangan, badan-badan usaha swasta, 
badan usaha milik pemerintah, bahkan menjadi lembaga-lembaga pemerintah menyimpan dana-dana yang dimilikinya. Melalui kegiatan perkreditan/pembiayaan serta berbaga jasa yang diberikan.

Kasmir (2001) mendefinisikan bank sebagai badan usaha yang menghimpun dana dari masyarakat dalam bentuk simpanan dan menyalurkannya kepada masyarakat dalam bentuk kredit atau bentuk-bentuk lainnya dalam rangka meningkatkan taraf hidup rakyat banyak.

Nurhasanah \& Adam (2017) penelitiannya menyatakan bank melayani kebutuhan permodalan serta melancarkan mekanisme sistem pembayaran bagi semua sektor perekonomian.

Ismail (2013) menyebutkan perbankan syariah yaitu segala sesuatu yang menyangkut bank syariah dan unit usaha syariah, mencakup kelembagaan, usaha, serta tata cara dan proses didalam melaksanakan kegiatan usahanya.

Bank Syariah menurut Sugihantoro (2011) adalah lembaga keuangan yang berfungsi sebagai perantara bagi pihak yang berkelebihan dana dengan pihak yang kekurangan dana, baik untuk kegiatan usaha maupun kegiatan lainnya sesuai dengan hukum Islam.

Ali (2008) penelitiannya mendefinisikan bank syariah sebagai sistem perbankan yang dalam operasionalnya tidak menggunakan sistem bunga (riba), spekulasi (maysir), dan ketidakpastian (gharar).

\section{METODE PENELITIAN}

Jenis dan sumber data serta metode penelitian yang digunakan dalam penulisan makalah ini merupakan data primer yang didapat dari hasil riset perpustakaan (Library Research) dengan mengadopsi pemikiran dan pendapat para ahli dan praktisi yang memiliki kaitan secara langsung dan tidak langsung dengan topik yang sedang dibahas, dilanjutkan dengan telaah pustaka yang sesuai dengan tema penelitian. Analisis dalam penelitian ini bersifat kualitatif dimana hasil penelitian dan pembahasan diuraikan dalam bentuk analisis deskriptif.
Metode kualitatif ini lebih menekankan pada pengamatan fenomena dan lebih meneliti kepada substansi makna dari fenomena tersebut. Analisis dan ketajaman peneltian kualitatif sangat dipengaruhi oleh kekuatan penggunaan kata dan kalimat, oleh karena itu Basri (2014) menyimpulkan bahwa fokus penelitan kualitatif adalah pada proses dan pemaknaan hasilnya. Mohamed et al, (2010) menyatakan perhatian penelitian kualitatif ini ini lebih tertuju pada elemen manusia, objek, institusi serta hubungannya atau interaksi antar elemen-elemen tersebut dalam upaya memahami suatu peristiwa, perilaku atau fenomena

\section{FENOMENA PERBANKAN SYARIAH DI INDONESIA}

Pelaku sistem ekonomi syariah yang dominan di Indonesia adalah sektor perbankan. Bank dengan segenap sistem dan fasilitas yang ditawarkan mampu menjadi aktor utama dalam transaksi ekonomi syariah. Dasar hukum (Legal standing) untuk landasan operasi bank syariah pertama kali adalah Undang-undang No. 07 Tahun 1992 tentang perbankan. Dengan adanya dasar hukum untuk perbankan dengan sistem syariah tersebut, maka pada tahun yang sama berdirilah Bank Muamalat sebagai pioneer dalam menawarkan konsep syariah kepada konsumen yang pada saat itu masih melakukan transaksi di bank-bank konvensional.

\section{Pada tahun 1998 pemerintah} memperbaharui regulasi perbankan syariah dengan menerbitkan Undang-undang No.10 Tahun 1998 tentang perbankan, disini semakin jelas dinyatakan bahwa dua sistem perbankan yang diakui oleh pemerintah yakni sistem perbankan konvensional dan sistem perbankan syariah. Pada tahun 2008 pemerintah republik Indonesia kembali mengeluarkan undang-undang No. 21 Tahun 2008 tentang Perbankan Syariah yang ditujukan untuk menyempurnakan undangundang sebelumnya. Nurhasanah dan Adam (2017) menyatakan regulasi terbaru ini semakin menegaskan eksistensi perbankan syariah didalam bisnis perbankan di Indonesia. 
Dengan semakin jelasnya regulasi tentang sistem perbankan syariah ini, pelaku perbankan nasional semakin bergairah untuk membentuk bank umum syariah, BPR syariah ataupun memdirikan unit usaha syariah (UUS) pada bank konvensional yang sudah berdiri sebelumnya. Hal ini ditandai dengan berdirinya beberapa bank umum yang menjalankan operasionalnya dengan sistem syariah. Mayoritas penduduk Indonesia yang beragama Islam menjadi salah satu faktor penyebab pihak perbankan melirik sistem perbankan yang menganut prinsip syariah. Bank dengan sistem konvensional identik dengan unsur ribawi, sementara praktek riba ini dilarang menurut keyakinan ajaran agama Islam.

Persentase pangsa pasar perbankan syariah pada kuartal pertama tahun 2021 menurut Otoritas Jasa Keuangan (OJK) tercatat sebesar $9,96 \%$, sementara pada akhir tahun 2017 jumlah persentase pengguna layanan perbankan syariah ini tercatat sebesar 5,78\%. Angka ini menunjukkan peningkatan yang lumayan pesat namun belum signifikan jika dibandingkan dengan komposisi penduduk Indonesia yang mayoritas beragama Islam. Dengan kata lain masih banyak terdapat warga negara Indonesia yang beragama Islam yang masih menggunakan layanan perbankan konvensional. Hal ini merupakan tantangan tersendiri bagi perbankan syariah. Oleh karena itu dalam jurnal ini akan dibahas problematika dan dinamika perbankan syariah di era globalisasi saat ini.

\section{HASIL DAN PEMBAHASAN}

\section{Problematika Bank Syariah}

Dalam penelitian yang dituliskan
kedalam jurnalnya Subandi $(2012)$
menyampaikan bahwa mayoritas pangsa
pasar perbankan adalah masyarakat ekonomi
kelas menengah ke bawah. Kehadiran
perbankan syariah diharapkan mampu
membantu mengatasi permasalahan
kemiskinan di Indonesia yang mayoritas
pendudukanya beragama Islam. Akan tetapi
dalam hal ini perbankan syariah belum
mampu berbuat banyak dalam mengelola
pangsa pasar potensial ini. Bank-bank

dengan sistem operasi konvensional mendominasi penguasaan market share dengan tingkat kesenjangan yang cukup tinggi.

Secara umum ada beberapa faktor yang mempengaruhi perkembangan perbankan syariah di Indonesia, yaitu:

1. Keterbatasan Sumber Daya Manusia

Manan (2012) penelitiannya menyebutkan sumber daya manusia merupakan faktor utama yang memiliki peran penting dalam perkembangan bank syariah. Maraknya pertumbuhan bank syariah tidak di imbangi kualitas SDM yang memadai, terutama yang khusus mengusai disiplin ilmu perbankan syariah. Bank syariah memang sudah lama dikenal di Indonesia akan tetapi lembaga atau perguruan tinggi yang khusus memberikan pendidikan ekonomi atau perbankan syariah masih terbatas. Hal yang turut mempengaruhi kualitas SDM adalah adanya transisi dari pegawai bank konvensional menjadi pegawai bank syariah, ini biasanya terjadi ketika bank konvensional mendirikan unit usaha syariah (UUS) akan tetapi tidak merekrut pegawai baru yang berlatar belakang disiplin ilmu ekonomi syariah melainkan hanya mengalih fungsikan pegawai dari bank konvensional yang sudah ada ke unit usaha syariah tersebut.

Berdasarkan data dari Badan Akreditasi Nasional Perguruan Tinggi (BAN-PT) tahun 2018, dari baru 10 prodi ekonomi syariah yang terakreditasi A, yang terakreditasi B berjumlah 99 prodi dan yang mendapatkan akreditasi $\mathrm{C}$ sebanyak 10 prodi. Dari pemaparan data statistik perbankan syariah, diketahui bahwa $38 \%$ pegawai bank syariah merupakan sarjana ekonomi konvensional, hanya 9,1\% berasal yang memiliki latar belakang ekonomi syariah.

2. Minimnya sosialiasi dan edukasi tentang perbankan syariah

Sosialiasi adalah suatu proses untuk mengkomunikasikan kebudayaan baru kepada masyarakat. Sosialisasi ini 
merupakan elemen yang sangat penting dalam memperkenalkan sesuatu hal kepada publik atau calon kosumen. Pembuatan iklan dan reklame merupakan salah bentuk sosialisasi kepada masyarakat selain sosialisasi yang dilakukan secara langsung dalam bentuk seminar, kajian dan pertemuan tatap muka lainnya. Sosialiasi dan edukasi ini tidak bisa hanya ditumpukan kepada bankir syariah akan tetapi ini juga patut menjadi perhatian bagi semua pihak (stakeholder) yang terkait secara langsung dan tidak langsung dengan perbankan syariah, seperti pemerintah, institusi pendidikan, maupun lembaga dan komunitas Islam (MUI, MES, Komunitas Masyarakat Anti Riba, dan lain-lain).

Hidayatinaa (2018) dalam penelitiannya menulis bahwa signifikansi pengaruh sosialisasi terhadap minat menabung masyarakat (studi kasus pada Bank Syariah Aceh) adalah sebesar 45,1\%, sisanya berasal dari faktor lain yakni kualitas pelayanan, lokasi dan promosi.

Ramdan (2010) dalam penelitian tesisnya menyatakan bahwa minimnya sosialisasi menjadi penyebab kurangnya pemahaman masyarakat terhadap keuangan dan perbankan syariah, hal ini terlihat dari belum banyaknya masyarakat yang mengakses layanan perbankan syariah.

3. Faktor layanan bank syariah yang belum optimal.

Faktor layanan merupakan faktor internal perbankan syariah. Bank merupakan lembaga keuangan yang bergerak dibidang jasa pelayanan, sehingga pelayanan ini menjadi faktor krusial untuk menarik minat calon pelanggan.

Junaidi et al, (2012) penelitiannya menyatakan persepsi kepuasan nasabah terhadap pelayanan bank syariah dibentuk atas 3 hal, yakni; a. tersedianya jaringan ATM, b. tersedianya fasilitas phone banking dan mobile banking, c. adanya call center yang renponsif untuk menampung keluhan nasabah.
Contoh lain yang menjadi kekurangan dalam hal pelayanan adalah keterbatasan jaringan kerjasama bank syariah untuk pemanfaatan fasilitas kartu debit atau kredit, dikarenakan bank syariah ini masih tergolong sebagai pendatang baru sehingga jaringan vendor (toko) dan merchant yang dimiliki pun belum sebanyak bank-bank konvensional. Kondisi ini sedikit banyak menyulitkan nasabah-nasabah yang memerlukan layanan bank syariah, sehingga ada nasabah yang mengeluh ketika kartu debit atau kredit bank syariah yang dimilikinya tidak bisa digunakan di kotakota besar diluar negeri seperti yang ditawarkan oleh bank-bank konvensional.

\section{Solusi Mengatasi Problematika Perbankan Syariah}

Penggunaan nama "syariah" tidak dapat dipungkiri merupakan senjata yang cukup ampuh untuk meraih minat calon nasabah khususnya dari kalangan umat Islam. Produk dan layanan juga dikemas sedemikian rupa dengan nama-nama berbau Islam. Akan tetapi penggunaan embel-embel syariah itu saja tidak cukup. Agar sistem perbankan syariah ini berkembang di Indonesia secara signifikan dan mampu bersaing dengan sistem dengan perbankan konvensional maka harus memperhatikan beberapa hal, diantaranya:

\section{Korelasi institusi pendidikan}

Untuk mencetak SDM yang handal dan memilki kompetensi dalam bidang perbankan syariah diperlukan adanya peranan atau campur tangan dari institusi pendidikan. Mengingat sektor perbankan syariah adalah salah satu sektor usaha yang sangat potensial dan saat ini sedang berkembang, kedepannya akan membutuhkan banyak tenaga kerja profesional. Maka institusi pendidikan perlu mempersiapkan SDM berkualitas yang siap terjun ke dalam bisnis perbankan syariah. Peran institusi pendidikan ini dimulai dari membangun jurusan atau program pendidikan yang khusus mempelajari ekonomi syariah. 
Institusi pendidikan juga diharapkan dapat menambah literasi yang membahas tentang perbankan syariah, disamping untuk mengedukasi masyarakat juga sebagai referensi bank syariah dalam menentukan arah kebijakan produk dan layanan.

2. Optimalisasi peran pemerintah

Pemerintah merupakan leading sector dalam upaya pengembangan perbankan syariah, peran pemerintah terlihat dalam pembuatan regulasi yang menjadi payung hukum bagi bank syariah dalam menancapkan eksistensinya. Disamping sebagai regulator, pemerintah juga diharapkan banyak melakukan edukasi tentang perbankan syariah kepada masyarakat agar mereka lebih memahami dan mengenal dunia perbankan syariah. Edukasi ini bisa berupa kegiatan sosialisasi yang dilakukan secara langsung kepada masyarakat, ataupun dengan penyebaran iklan layanan masyarakat tentang perbankan syariah melalui pemanfaatan media. Kegiatan edukasi ini bisa dilaksanakan secara langsung oleh pemerintah atau dilakukan dengan menggandeng institusi pendidikan, organisasi keagamaan dan bahkan dengan pihak perbankan syariah itu sendiri.

Pemerintah juga perlu memberi pemahaman terhadap kelompok yang anti dengan penerapan ekonomi syariah karena dianggap berafiliasi dengan ajaran agama tertentu, ada semacam kekhawatiran oleh kelompok ini bahwa sistem yang berasal dari agama Islam lambat laun akan menggantikan dasar negara Indonesia. Padahal sejarah mencatat bahwa umat Islam Indonesia adalah umat yang berjiwa besar dan telah berbesar hati menerima penghapusan klasusul sila pertama yakni "kewajiban menjalanan syariat Islam bagi pemeluknya". Perlu dijelaskan bahwa sistem ekonomi Islam lebih bersahabat daripada sistem ekonomi kapitalis maupun sosialis, karena sistem ekonomi Islam itu sendiri lebih mengedepankan unsur maslaha dan manfaat daripada pengerukan keuntungan.

3. Peningkatan layanan oleh perbankan syariah

Kualitas pelayanan merupakan kunci utama dalam menarik minat calon nasabah, bank syariah harus lebih peka terhadap kebutuhan nasabahnya. Layanan ini bisa dalam bentuk fasilitas produk, jaringan kantor dan ATM serta merchant tempat penggunaan fasilitas dari bank syariah.

Pemanfaatan teknologi untuk keperluan bertransaksi juga perlu diperhatikan, sebab sekarang adalah saat dimana manual banking system tidak lagi menjadi opsi utama untuk melakukan transaksi. Mobilitas yang tinggi, gaya hidup dan faktor kebutuhan membuat transaksi perbankan dapat dilakukan dimana saja, otomatis bank harus bisa menyesuaikan diri dengan ritme tersebut. Dalam hal peningkatan layanan ini bank syariah harus bersifat adaptif terhadap kebutuhan nasabah serta lebih inovatif dalam membuat terobosan-terobosan baru untuk memanjakan nasabah.

\section{KESIMPULAN}

Untuk bertahan dan berkembang di era globalisasi bank syariah harus mampu menjawab tantangan pasar, bank syariah harus bisa mengimplementasikan nilai-nilai keislaman secara utuh dan bukan hanya menjadi bank konvensional yang berbaju syariah, serta bersikap adaptif dan inovatif terhadap perkembangan yang terjadi pada pasar perbankan syariah. Upaya kongkrit yang perlu dilakukan untuk membantu perkembangan bank syariah antara lain;

a. Penguatan Sumber Daya Manusia (SDM) perbankan syariah.

b. Peningkatan peran pemerintah dalam rangka penguatan kelembagaan bank syariah.

c. Optimalisasi edukasi masyarakat tentang perbankan syariah. 
2022, Jurnal Tabarru' : Islamic Banking and Finance 5 (1) : 34 - 40

d. Pengembangan (ekstensifikasi/ intensifikasi) produk dan pelayanan bank syariah.

\section{DAFTAR PUSTAKA}

Ali, Zainuddin. 2008. Hukum Perbankan Syariah. Sinar Grafika. Jakarta.

Basri, Hasan. 2014. Using Qualitative Research In Accounting And Management Studies, Not A New Agenda. Journal of US-China Public Administration, 11(10), p. 831-838.

Hidayatinaa, 2018. Pengaruh Sosialisasi Perbankan Syariah terhadap Minat Menabung Nasabah (Studi Kasus Pada PT. Bank Aceh Syariah cabang Lhokseumawe). Laporan Penelitian. Institut Agama Islam Negeri (IAIN) Lhokseumawe.

Ismail. 2013. Perbankan Syariah. Penerbit Kencana Prenada Media Group. Jakarta.

Jaharuddin dan Sutrisno, Bambang. 2019. Pengantar Ekonomi Islam. Salemba Diniyah. Jakarta.

Junaidi, Achmad Taviv., Hadiwijoyo., Troena, Eka Afnan., \& Triyuwono, Iwan. 2012. Analisis Pengaruh Kualitas Layanan, Keadilan dan Kepuasan Nasabah Terhadap Loyalitas Nasabah Bank Syariah (Studi pada Nasabah Bank Syariah di Propinsi Riau). JAM Jurnal Aplikasi Manajemen, 10(1), p. 161-176.

Kasmir. 2001. Bank dan Lembaga Keuangan Lainnya (Edisi Revisi 2001). PT. Raja Grafindo Persada. Jakarta.

Manan, Abdul. 2012. Hukum Ekonomi Syariah: dalam Prekspektif Kewenangan Peradilan Agama. Kencana. Jakarta.

Mohamed, Z M., Abdul Majid, A H,. \& Ahmad, N. 2010. Tapping New Possibility In Accounting Research, In Qualitative Research, Malaysian Case, Penerbit Universiti Kebangsaan Malaysia. Kuala Lumpur.
Nurhasanah, Neneng., \& Adam, Panji. 2017. Hukum Perbankan Syariah: Konsep dan Regulasi. Sinar Grafika. Jakarta.

Prasetyo, Yoyok. 2018. Ekonomi Syariah. Aria Mandiri Group. Bandung.

Ramdan, Edi. 2010. Pengaruh Minimnya Sosialisasi Terhadap Minat Masyarakat Memilih Bank Syariah. Tesis.

Sjahdaini, Sutan Remy. 2009. Perbankan Islam dan Kedudukannya Dalam Tata Hukum Perbankan Indonesia. Pustaka Utama Grafiti. Jakarta.

Subandi. 2012. Problem dan Solusi Perbankan Syariah Kontemporer di Indonesia. Jurnal At Tahrir, 12(1), p. $1-19$.

Sugihantoro. 2011. Peluang Bank Syariah Dalam Pemberdayaan Ekonomi Ummat. STAIN Press Ponorogo. 